\title{
A Clinical Trial on the Effecacy of Sadvindu Taila Nasya on Sirashool W.S.R to Frontal Sinuisitis
}

\author{
Dr. Sushanta Kumar Sahoo M.D.(kayachikitsa), Ph.D, PGCHFWM ${ }^{1 *}$, Dr. Jayanti Sahoo BAMS ${ }^{2}$ \\ ${ }^{1}$ Associate Professor, Deptt. Of kayachikitsa, Gangasheel Ayurvedic Medical College, Bareilly, Uttar Pradesh India \\ ${ }^{2}$ Medical officer, Gangasheel Ayurvedic medical college, Bareilly Uttar Pradesh India
}

DOI: $10.36348 /$ sijtcm.2020.v03i03.004

| Received: 25.02.2020 | Accepted: 07.03.2020 | Published: 30.03.2020

*Corresponding author: Dr. Sushanta Kumar Sahoo

\section{Abstract}

Sinusitis one of the most troublesome diseases disturbing the usual daily activities. It is manifested by severe headache, nasal discharge, sneezing etc which creates a great problem. For its management analgesics, nasal decongestants \& finally curettage of the sinus to remove the fluid deposit is adopted in modern medical science. However in Ayurveda Nasya \& Dhumapan is best applied in this connection. A clinical trial was carried out to evaluate the effectiveness of Sadvindu Taila nasal drop in the management of frontal sinusitis. For this purpose total 40 patients of frontal sinusitis were collected from the OPD \& IPD of Gangasheel Ayurvedic medical college, Bareilly(UP) as per the selection criteria. They were divided into two groups i.e. trial group \& control group (consisting of 20 patients each) to whom the nasal drop Sadvindu Taila \& Otrivin (Xylometazoline hydrochloride) nasal drop was given respectively. The trial drug was given in the prescribed dose for 7 days under Nasya \& Dhumapana procedure. The control drug, in normal way only nasal instillation. After 7 days evaluation was done depending on the subjective \& objective parameters. For statistical evaluation, mean $\pm \mathrm{SD}$, paired t-test was calculated. It was observed that the trial drug is very much effective in decreasing Headache, sneezing, nasal discharge \& other allergic manifestation. Radiological the fluid level also decreased. Though the drug is better effective but it is not accepted by all the patients as it causes severe irritation in nasal mucosa. With the total study it can be concluded that the trial drug Sadvindu Taila has a great scope in the management of sinusitis, especially frontal sinusitis. Further studies are required to establish the drug more scientifically.

Keywords: Sinusitis, Sadvindu Taila, Headache, Sneezing.

Copyright @ 2020: This is an open-access article distributed under the terms of the Creative Commons Attribution license which permits unrestricted use, distribution, and reproduction in any medium for non-commercial use (NonCommercial, or CC-BY-NC) provided the original author and source are credited.

\section{INTRODUCTION}

Sinusitis one of the most troublesome diseases disturbing the usual daily activities. It is manifested by severe headache, nasal discharge, sneezing etc which creates a great problem. In Ayurveda this condition is called Pratishyaya, it may be acute or chronic. Particularly Sinusitis can be correlated with Kaphaja pratishyaya or Jeerna Pratishyaya[1]. For its management analgesics, nasal decongestants \& finally curettage of the sinus to remove the fluid deposit is adopted in modern medical science [2]. However in Ayurveda Nasya \& Dhumapan is best applied in this connection. In the treatment of Kaphaja shiroroga Maharshi Charak has mentioned the procedure of Swedan, Dhumapana and Pradhamana Nasya[3]. But due to convenience and easy availability here Sadvindu Taila has been selected for its Ushna, Katu, Tikshna and srotosodhaka property [4]. Besides this in Charak Samhita, Shirovirechana is indicated in UrdhwaJaturgata (supra clavicular) diseases like
Manyasthambha, Galagraha, Hanugraha, Pinasa, Pratishyaya etc[5]. Hence in this connection a clinical trial was carried out to evaluate the effectiveness of Sadvindu Taila nasal drop in the management of frontal sinusitis.

\section{AIM}

To evaluate the efficacy of Sadvindu Taila on sinusitis especially frontal sinusitis.

\section{MATERIAL \& METHODS}

Total 40 no of patients of frontal sinusitis having various complaints were collected from the OPD \& IPD of Gangasheel Ayurvedic medical college, Bareilly (UP). They are divided in two groups consisting of 20 patients each. Out of the cases registered, all had a history of treatment several times earlier. Detailed examination \& other investigations were properly carried out in a predetermined Performa. Prior to trial, the patients were explained regarding the 
procedure of nasya and an oral consent regarding the procedure and drug was taken from the patients registered. Details of drug, dose, duration is given bellow.

\begin{tabular}{|l|c|c|}
\hline & Trial group & Control group \\
\hline No. of Patient & 20 & 20 \\
\hline Drug & $\begin{array}{l}\text { Sadvindu taila nasya- 6 drops in each } \\
\text { nostril once daily followed by dhumapan }\end{array}$ & $\begin{array}{l}\text { Otrivin (Xylometazoline hydrochloride) nasal } \\
\text { drop, 4drops in each nostril twice daily. }\end{array}$ \\
\hline Duration & 7 days & 7 days \\
\hline Follow up & On every 7 days up to 1 month & On every 7 days up to 1 month \\
\hline
\end{tabular}

\begin{tabular}{|c|c|c|}
\hline \multicolumn{3}{|c|}{ Selection \& Exclusion criteria } \\
\hline Selection Criteria: & Exclusion criteria: & \\
\hline 1. Age: $8-70 \mathrm{yrs}$ & Sinusitis associated witl & \\
\hline 2. Sex : Both & & \\
\hline 3. Having complain of pain \& tenderness on sinus area & T.B. & Epistasis \\
\hline 4. $\mathrm{X}$ - ray PNS suggestive of sinusitis & Hypertension & Carcinoma \\
\hline 5. Heaviness in head & Influenza & VDRL (+ve) \\
\hline & Nasal polyp & Diabetes Mellitus \\
\hline & Pre \& postnatal period & SOL \\
\hline
\end{tabular}

Study Period: $\quad 1^{\text {st }}$ January 2014 to $31^{\text {st }}$ December 2014

\section{Study Design}

20 cases of frontal sinusitis were treated with the trial drug \& 20 cases with control drug. After treatment both groups were compared.

\section{Single group:}

Double group:

Diet \& Advice:
Trial Group (BT) $\leftrightarrow$ Trial Group (AT)

(Effectiveness of the trial drug before and after treatment can be assessed)

Control Group (BT) $\leftrightarrow$ Ccontrol Group (AT)

(Effectiveness of the control drug before and after treatment can be assessed)

Trial Group $\leftrightarrow$ Control Group

(Effectiveness of the trial \& control drug can be compared)

Both the groups were strictly advised to avoid Kaphaja Ahar Vihar like Ice-cream, curd, cold drinks, exposure to cold etc.

\section{Procurement of trial \& control drug}

The trail drug Sadvindu Taila was purchased from the local market manufactured by Shree Baidyanath Ayurveda Bhawan \& the control drug.
Otrivin Nasal drop (Xylometazoline hydrochloride) manufactured by Novartis Consumer Health, was purchased from the local market.

Parameters for efficacy study

\begin{tabular}{|l|ll|}
\hline Subjective parameters & \multicolumn{1}{|c|}{ Objective parameters } \\
\hline 1. Nasal discharge & 1. Peripheral eosinphil count \\
2. Headache & 2. Eosinphil count from nasal discharge \\
3. Sneezing & 3. Nasal $\mathrm{pH}$ \\
\hline
\end{tabular}

\section{Clinical Assessment of the Results} as follows.

The assessment of the result was done basing on the percentage of improvement in different sign $\&$ symptoms

1. Cured

2. Max. Improvement

3. Moderate improvement

4. Mild improvement

5. No improvement
: $100 \%$ improvement in different sign symptoms.

: $75-100 \%$ of improvement in sign \& symptoms.

: $50-75 \%$ of improvement in sign \& symptoms.

: $25-49 \%$ of improvement in sign \& symptoms.

: $<25 \%$ of improvement in sign \& symptoms. 


\section{Statistical Assessment of Results}

For the purpose of statistical assessment of the result, mean $\pm \mathrm{SD}$ value before treatment of different sign \& symptoms was compared with that of after treatment.

T - Test was used for the purpose of the test of significance. The effectiveness of the nasal drop has been assessed through the p-value.
Null Hypothesis: For the purpose of assessment a Null Hypothesis was set "Let the nasal drop Otrivin nasal drop is more effective in treating Frontal sinusitis than sadvindu taila.

\section{Follow up}

All the patients were advised to attend the OPD of Kayachikitsa deptt weekly, after the date of completion of therapy for 1 month, so that follow up was made to observe any untoward effect or recurrence.

Table -1: (Statistical analysis showing the effectiveness of the trial drug to different signs and symptoms)

\begin{tabular}{|l|l|l|l|l|l|l|l|}
\hline $\begin{array}{c}\text { SI } \\
\text { No. }\end{array}$ & \multicolumn{1}{|c|}{$\begin{array}{c}\text { Sing \& } \\
\text { Symptoms }\end{array}$} & \multicolumn{2}{|c|}{ Mean \pm S. D. } & $\begin{array}{c}\text { Degree of } \\
\text { freedom }\end{array}$ & t-value & P-value & Remark \\
\cline { 3 - 7 } & Nasal discharge & $1.83 \pm 0.58$ & $0.6 \pm 0.92$ & 19 & 8.01 & $<0.001$ & $\begin{array}{l}\text { Highly } \\
\text { significant }\end{array}$ \\
\hline 2 & Headache & $1.23 \pm 0.49$ & $0.36 \pm 0.54$ & 19 & 9.35 & $<0.001$ & $\begin{array}{l}\text { Highly } \\
\text { significant }\end{array}$ \\
\hline 3 & Sneezing & $2.4 \pm 0.75$ & $1.2 \pm 0.74$ & 19 & 8.12 & $<0.001$ & $\begin{array}{l}\text { Highly } \\
\text { significant }\end{array}$ \\
\hline 4 & $\begin{array}{l}\text { Peripheral } \\
\text { eosinphil\% }\end{array}$ & $18.8 \pm 11.25$ & $9.43 \pm 5.37$ & 17 & 7.24 & $<0.001$ & $\begin{array}{l}\text { Highly } \\
\text { significant }\end{array}$ \\
\hline 5 & $\begin{array}{l}\text { Nasal eosin- } \\
\text { phil count }\end{array}$ & $12.58 \pm 4.70$ & $6.18 \pm 3.20$ & 15 & 10.63 & $<0.001$ & $\begin{array}{l}\text { Highly } \\
\text { significant }\end{array}$ \\
\hline 6 & $\begin{array}{l}\text { Nasal pH } \\
7\end{array}$ & $7.29 \pm 0.59$ & $6.88 \pm 0.58$ & 19 & 6.55 & $<0.001$ & $\begin{array}{l}\text { Highly } \\
\text { significant }\end{array}$ \\
\hline 7 & $\begin{array}{l}\text { Radiological } \\
\text { Changes }\end{array}$ & $86 \pm 0.66$ & $0.93 \pm 0.77$ & 19 & 6.89 & $<0.001$ & $\begin{array}{l}\text { Highly } \\
\text { significant }\end{array}$ \\
\hline
\end{tabular}

S.D. - Standard deviation, BT - Before treatment

$\mathrm{t}$ - value - Test of significance, AT - After treatment

The $\mathrm{p}$ - value $(<0.001)$ of different sign and symptoms indicates that the trial drug is highly significant in respect to different sign and symptoms at $0.1 \%$ level.

Table -2: (Statistical analysis showing the effectiveness of the control drug to different signs and symptoms)

\begin{tabular}{|c|c|c|c|c|c|c|c|}
\hline \multirow{2}{*}{$\begin{array}{l}\text { Sl } \\
\text { No. }\end{array}$} & \multirow{2}{*}{$\begin{array}{c}\text { Sing \& } \\
\text { Symptoms }\end{array}$} & \multicolumn{2}{|c|}{ Mean \pm S. D. } & \multirow{2}{*}{$\begin{array}{l}\text { Degree of } \\
\text { freedom }\end{array}$} & \multirow{2}{*}{ t-value } & \multirow{2}{*}{ P-value } & \multirow{2}{*}{ Remark } \\
\hline & & BT & AT & & & & \\
\hline 1 & Nasal discharge & $1.66 \pm 0.53$ & $0.56 \pm 0.61$ & 19 & 8.49 & $<0.001$ & $\begin{array}{l}\text { Highly } \\
\text { significant }\end{array}$ \\
\hline 2 & Headache & $1.73 \pm 0.51$ & $0.6 \pm 0.66$ & 19 & 9.26 & $<0.001$ & $\begin{array}{l}\text { Highly } \\
\text { significant }\end{array}$ \\
\hline 3 & Sneezing & $2.23 \pm 0.88$ & $1.16 \pm 0.73$ & 19 & 7.15 & $<0.001$ & $\begin{array}{l}\text { Highly } \\
\text { significant }\end{array}$ \\
\hline 4 & $\begin{array}{l}\text { Peripheral } \\
\text { eosinphil count }\end{array}$ & $17.76 \pm 9.15$ & $10.96 \pm 5.45$ & 17 & 6.92 & $<0.001$ & $\begin{array}{l}\text { Highly } \\
\text { significant }\end{array}$ \\
\hline 5 & $\begin{array}{l}\text { Nasal eosin- } \\
\text { phil count }\end{array}$ & $14.11 \pm 4.05$ & $7.08 \pm 2.83$ & 15 & 8.03 & $<0.001$ & $\begin{array}{l}\text { Highly } \\
\text { significant }\end{array}$ \\
\hline 6 & Nasal pH & $7.03 \pm 0.56$ & $6.99 \pm 0.65$ & 19 & 7.31 & $<0.001$ & $\begin{array}{l}\text { Highly } \\
\text { significant }\end{array}$ \\
\hline 7 & $\begin{array}{l}\text { Radiological } \\
\text { Changes }\end{array}$ & $2.63 \pm 0.65$ & $2.16 \pm 0.81$ & 19 & 3.53 & $<0.005$ & $\begin{array}{l}\text { Highly } \\
\text { significant }\end{array}$ \\
\hline
\end{tabular}

S.D. - Standard deviation BT - Before treatment

$\mathrm{t}$ - Value - Test of significance AT - After treatment

The $\mathrm{p}$ - value $(<0.001)$ of different sign and symptoms indicates that the trial drug is highly significant in respect to different sign and symptoms at $0.1 \%$ level. 
Discussion on statistical analysis of the effectiveness on various sign \& symptoms with trial drug and control drug

On the point of statistical adjudication the cardinal signs and symptoms as fixed under the criteria of assessment were individually calculated as highly significant at $0.1 \%$ level having $\mathrm{p}$ - value $<0.001$.

Comparing to the above sign and symptoms under control drug were individually calculated as highly significant at $0.1 \%$ level having $\mathrm{p}$-value $<0.001$ expect the radiological evidences which was little less being $<0.005$.

Exploring the above adjudication the Null hypothesis which was framed earlier is here with rejected and it is confirmed that the trial drug is exceeding effective considering to the control drug.

\section{Assessment of result}

The result obtained were very carefully assessed keeping behind the clinical response, peripheral and nasal Eosinophil count, radiological improvement, alteration of nasal $\mathrm{pH}$ and statistical adjunction.

\section{Acceptability of the trial drug}

So far as the percentage of relief obtained in different sign and symptoms the trial drug can be accepted for the treatment of sinusitis. It is very much effective in relieving the chief complains which disturbs the patients very much like Headache, Nasal discharge, sneezing.

\section{SUGGESTIONS}

Though the trial drug is effective in the treatment of sinusitis, still it is not accepted by some patients especially in younger age group and ladies. Because it causes much irritation in nose which was not tolerated by some patients

\section{CONCLUSION}

With the total study it can be concluded that the trial drug Sadvindu taila has a great scope in the management of sinusitis, especially frontal sinusitis. Further studies are required to establish the drug more scientifically.

\section{REFERENCES}

1. Vaidya, Y.T., Sushruta, S. (2012). (Dalhana Nibandha samgraha tikaa), published by Chaukhambha Surbharti Prakashana, Varanasi, edi, P.No. 651, (Su. U. 24/9-10)

2. Musher, S. H. Logan Turner's Diseases of the Nose, Throat \& Ear, Head \& Neck Surgery, Published by CRC press, Taylor \& Francis group, $11^{\text {th }}$ edition, P. No. 80.

3. Dr. Brahmananda, T., Charak, S. (2012). Vol-II, published by Chaukhambha Surbharti Prakashana, Varanasi, edi, P.No. 900, (Ch. Chi.26/180)

4. Prof. Sidhinandan, M., Bhaishajya, R. (2014). Chaukhamba Surbharati Publication, Varanasi, edi. 2, P.No. 1020

5. Dr. Brahmananda, T. (2012). Charak Samhita VolII , published by Chaukhambha Surbharti Prakashana, Varanasi, edi, P. No. 1187, (Ch. Si. 2/22). 